\title{
Meibom-mirigy-diszfunkció és a száraz szem
}

\author{
Diagnosztikai és kezelési lehetôségek
}

\author{
Kovács Balázs dr. ${ }^{1}$. Láng Boglárka ${ }^{2}$ - Takácsi-Nagy Anna dr. ${ }^{2}$ \\ Horváth Györgyi dr. ${ }^{3}$ - Czakó Cecília dr. ${ }^{4}$ - Csorba Anita dr. ${ }^{4}$ \\ Kiss Huba dr. ${ }^{4}$ - Szalai Irén dr. ${ }^{4}$. Nagy Zoltán Zsolt dr. ${ }^{4} 5$. Kovács Illés dr., \\ ${ }^{1}$ Kaposi Mór Megyei Kórház, Szemészeti Osztály, Kaposvár \\ ${ }^{2}$ Pécsi Tudományegyetem, Gyógyszerésztudományi Kar, Gyógyszertechnológiai és Biofarmáciai Intézet, Pécs \\ ${ }^{3}$ Pécsi Tudományegyetem, Gyógyszerésztudományi Kar, Farmakognóziai Intézet, Pécs \\ ${ }^{4}$ Semmelweis Egyetem, Általános Orvostudományi Kar, Szemészeti Klinika, Budapest \\ ${ }^{5}$ Semmelweis Egyetem, Egészségtudományi Kar, Budapest
}

\begin{abstract}
A szárazszem-panaszok hátterében gyakran áll Meibom-mirigy-diszfunkció, melynek felismerése kiemelten fontos a hatékony kezelés érdekében. A Meibom-mirigyek kóros múködése miatt a termelt lipid nem oszlik el megfelelően a szemfelszínen, így a könnyfilm párolgása fokozódik. A könnytermelési zavar következtében szárazszem-panaszok alakulnak ki, melyek a hagyományos könnypótló kezelésre rendszerint csak átmenetileg javulnak. A Meibom-mirigy-diszfunkciót gyakran kíséri a szemhéjszél Demodex-atka-fertőzése - az atka eradikálása szükséges a mirigyek múködésének helyreállításához és ezáltal a panaszok megszüntetéséhez. A Meibom-mirigy-diszfunkció a leggyakrabban enyhe formában jelentkezik; a terápia ilyenkor a beteg által is elvégezhető szemhéjtisztításból áll, míg a gyógyszeres kezelés csak az előrehaladottabb, kifejezett gyulladással járó formákban szükséges. Az összefoglaló áttekinti a Meibom-mirigy-diszfunkció klinikai jeleivel és kezelésével kapcsolatos legfontosabb tudnivalókat, különös tekintettel a Demodex-fertőzés felismerésére és kezelésére vonatkozóan.
\end{abstract}

Orv Hetil. 2021; 162(2): 43-51.

Kulcsszavak: Meibom-mirigy-diszfunkció, száraz szem, Demodex atka

\section{Meibomian gland dysfunction and dry eye}

\section{Diagnosis and treatment}

The onset of dry eye complaints is often a result of Meibomian gland dysfunction and its diagnosis is essential for effective treatment. In the case of Meibomian gland dysfunction, there is an increased evaporation of the tear film due to the abnormal secretion of lipids that cannot spread on the ocular surface. The treatment of dry eye complaints associated with Meibomian gland dysfunction with tear supplementation is usually ineffective and only results in an intermittent relief of complaints. Meibomian gland dysfunction is often associated with Demodex infestation of the eyelids, and eradicating the mites is essential to re-establish normal meibum production and thus, decreasing ocular complaints. In most cases, Meibomian gland dysfunction is mild, and the treatment of these forms is based on ocular hygiene performed by the patient, while only more advanced forms with inflammatory processes require pharmacologic treatment. This review summarizes the most important knowledge on the clinical signs and treatment of Meibomian gland dysfunction with particular attention to the diagnosis and treatment of ocular Demodex infection.

Keywords: Meibomian gland dysfunction, dry eye, Demodex mites

Kovács B, Láng B, Takácsi-Nagy A, Horváth Gy, Czakó C, Csorba A, Kiss H, Szalai I, Nagy ZZs, Kovács I. [Meibomian gland dysfunction and dry eye. Diagnosis and treatment]. Orv Hetil. 2021; 162(2): 43-51.

(Beérkezett: 2020. június 22.; elfogadva: 2020. július 25.) 


\section{Rövidítések}

DEWS = Dry Eye Workshop; MGD = (Meibomian gland dysfunction) Meibom-mirigy-diszfunkció; OSDI $=$ (Ocular Surface Disease Index) a szemfelszíni betegséget jellemző index

\section{Az egészséges könnytermelés}

A szaruhártya védelméhez és táplálásához, valamint a sima optikai felszín biztosításához, ezáltal a jó látáshoz elengedhetetlenül szükséges az egészséges könnyfilm. A könnyfilm összetett, többrétegú folyadék, melyet az orbita felső-külső részén elhelyezkedő fő könnymirigy és a szem körüli járulékos könnymirigyek termelnek. A könnyfilm legkülső, lipidrétegét a szemhéjakban elhelyezkedő Meibom-mirigyek termelik, és ennek a fázisnak a fó feladata a könny párolgásának csökkentése. A középső vizes fázis a fö könnymirigy szekrétuma, míg a legbelső mucinosus fázist, mely a könny megtapadását biztosítja, a kötőhártyában levő kehelysejtek termelik. A felső szemhéj le-fel mozgása minden egyes pislantással új, friss könnyréteget oszlat el a szaruhártya felszínén, így biztosítva a szemfelszín védelmét. A Meibom-mirigyek által termelt lipidet (meibum) is a rendszeres pislantás oszlatja el a szemfelszínen, de idősebb korban és ritkább pislantással járó koncentrált munkavégzés (például monitor előttti munkavégzés) esetén a meibum a szemhéjszélen összegyúlik. A meibum mennyiségét és minőségét az életkor és a környezeti faktorok mellett számos egyéb tényező befolyásolja, mint például hormonális, neuralis hatások, fertőzéses, valamint gyulladásos folyamatok.

\section{A Meibom-mirigy-diszfunkció}

A Meibom-mirigy-diszfunkció az egyik leginkább aluldiagnosztizált és alulkezelt szemészeti betegség; előfor- dulása a népességben 30,5-68,3\% közötti [1-3], és az ún. evaporatív száraz szem kialakulásához vezethet. 2011-ben a száraz szem patofiziológiájának és kezelésének jobb megértése iránti igény hívta életre az International Workshop on Meibomian Gland Dysfunction - egy, a Meibom-mirigy-diszfunkcióval foglalkozó szakértói bizottság - létrehozását. Az MGD Workshop által meghatározott definíció szerint a Meibom-mirigy-diszfunkció „a Meibom-mirigyek krónikus diffüz müködészavara, mely általában a kivezetöcsöpek elzáródásával és/vagy a mirigymüködés minôségi/mennyiségi zavarával jár. Ezek aztán a könnyfilm eltéréseibez, továbbá szemfelszini irritáció, klinikailag is látható gyulladás és szemfelszini betegség kialakulásához vezethetnek". Meibom-mirigy-diszfunkció kialakulását okozhatják szemészeti okok, mint a szemhéjak gyulladása, kontaktlencse-viselés, szemszárazság, Demodex folliculorum okozta fertőzés, glaukóma elleni szemcseppek tartós alkalmazása; továbbá általános állapotok, mint az öregedés, a menopausa, bizonyos autoimmun betegségek (Sjögren-szindróma, szisztémás lupus erythematosus, rheumatoid arthritis, psoriasis), atópiás állapot és rosacea jelenléte; illetve bizonyos gyógyszerek (postmenopausalis hormonterápia, antihisztaminok, antidepresszánsok, retinoidok) szedése [2]. A Meibom-mirigyek múködésének zavara megnyilvánulhat túlmúköóésben és alulmúködésben, ezen túlmenően megkülönböztetünk primer és szekunder formákat is (1. ábra). Ugyanakkor mindegyik forma a termelt meibum összetételének megváltozásához vezet, ami a könnyfilm párolgásának fokozódásán keresztül szárazszem-tünetek kialakulását okozza.

Meibom-mirigy-diszfunkció esetén a kivezetőcsövek beszúkülnek, ami miatt a termelődő lipidek összetétele megváltozik, és a besúrúsödött, viaszos lipid a szemhéjszélen összegyúlve a kivezetőcsövecskék elzáródását okozza (2. ábra). A besűrúsödött lipid az összetételéből

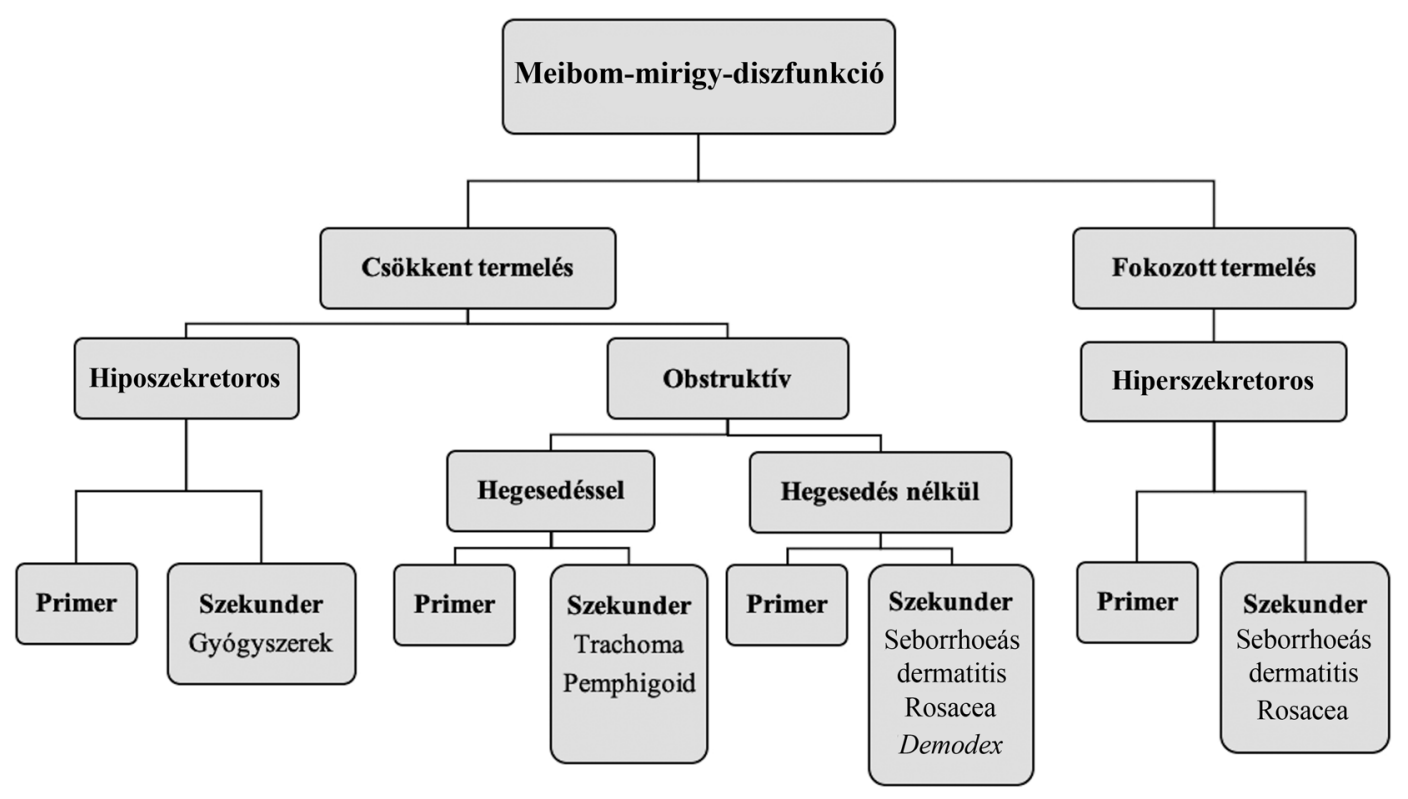



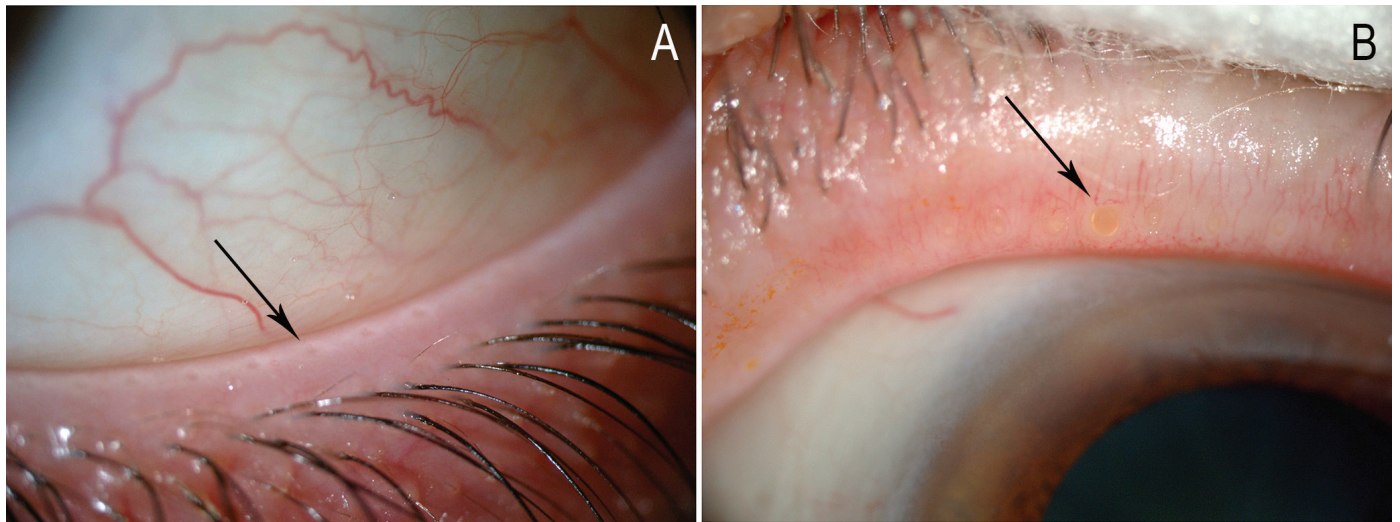

2. ábra

Ép Meibom-mirigy-múködés esetén a kivezetónyílásokból (nyíl) olajos lipid ürül (A), míg Meibom-mirigy-diszfunkció esetén a kivezetőcsövek nyílását viaszos, sűrú meibum zárja el (B). Kóros esetben teleangiectasiák is megjelennek a szemhéjszélen

adódóan gyulladáskeltő hatású, és elősegíti a baktériumok elszaporodását is [4]. Szemfelszíni diszkomfortot jelző személyek közel kétharmadában a Meibom-mirigy kivezetőnyílásainak elzáródását, a könnyfilm instabilitását és fokozott könnypárolgást, valamint a szaruhártya és a kötőhártya hámsejtjeinek károsodását írták le [5]. Meibom-mirigy-diszfunkció esetén gyakori a szemhéjszélek krónikus gyulladása is, melynek hátterében sokszor bakteriális (például Staphylococcus aureus) [6] vagy a Demodex szőrtüszőatka okozta fertőzés áll [7-9]. Az ilyen, szemhéjszéli és szemfelszíni gyulladással társuló krónikus formák kezelése nehéz, mert a hagyományos könnypótló kezeléssel a szárazszem-panaszok csak átmenetileg javulnak [10].

\section{A szembéjszéli Demodex-fertözés}

Az arc- és szemhéjak bőrén és a szempillák tövében egészséges személyekben is megtalálhatók Demodex atkák, ugyanakkor előfordulásuk az életkorral nő [11],

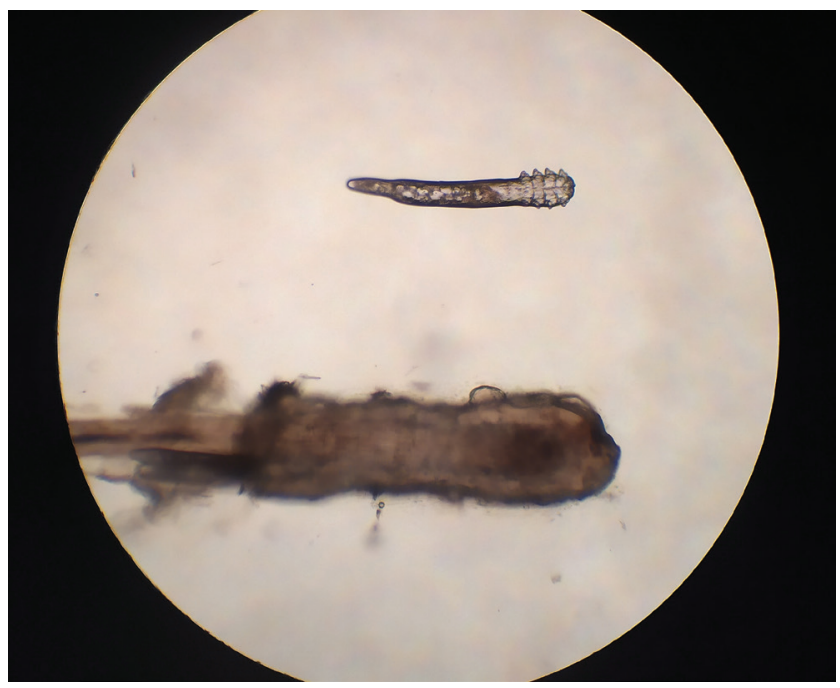

3. ábra $\mid$\begin{tabular}{l|l} 
Demodex atka mikroszkópos képe egy eltávolított szőrtüsző \\
mellett
\end{tabular} mellett illetve magasabb arányban fordul elő kontaktlencsét viselókben [12] és rosaceában is [13]. Bizonyos esetekben ezek a mikroszkopikus paraziták patogénné válhatnak, és Meibom-mirigy-diszfunkció, illetve szemhéjszéli gyulladás (blepharitis) alakulhat ki [14]. A Demodex atkák sebummal táplálkoznak, ezért jellemzően a szőrtüszők és a faggyúmirigyek környékén élősködnek, illetve lipázokat termelnek, melyek a meibumot bontják, egyrészt a könnyfilm lipidrétegének károsodását okozva, másrészt a lebontási termékek a szaruhártya-epithelsejtekre toxikusak, és szemfelszíni irritációs panaszokat okoznak [15]. A Demodex atkák kimutatása történhet a bőrből biopsziával vagy in vivo konfokális mikroszkópiával, illetve az eltávolított szempillák fénymikroszkópos vizsgálatával [16, 17] (3. ábra).

\section{Tünetek}

A Meibom-mirigy-diszfunkció okozta jellegzetes panaszok a károsodott könnytermelés miatt jelentkező irritáció, égő és idegentest-érzés, valamint szárazszem-érzés, melyek múkönny alkalmazásakor is csak időlegesen enyhülnek. A kontaklencse-viselők gyakran panaszkodnak arra, hogy nem tudják már olyan hosszú ideig hordani a lencsét, és hogy jobban irritálja őket. A szemhéjak széle hyperaemiás, teleangiectasiák jelennek meg, és a szempillák tövében gyakran pörk, illetve sárgás váladék gyưlik össze. Szintén a Demodex-fertőzés jele a szempillák tövét gyưrü alakban körbevevő lerakódás, az ún. 'collarette' megjelenése (4. ábra). A súlyosabb formákban a beteg számára a legfontosabb panaszok a krónikus, hagyományos kezelésre nem gyógyuló vörös, égő, irritált szem, a fokozott könnyezés, váladékozás okozta homályos látás, illetve a szemhéjszél kivörösödése (5. ábra).

\section{Diagnózis}

Tünetmentes személyekben a Meibom-mirigy-diszfunkció kimutatására a meibumürülés próbája javasolt az alsó szemhéj középső részének megnyomásával, valamint az 

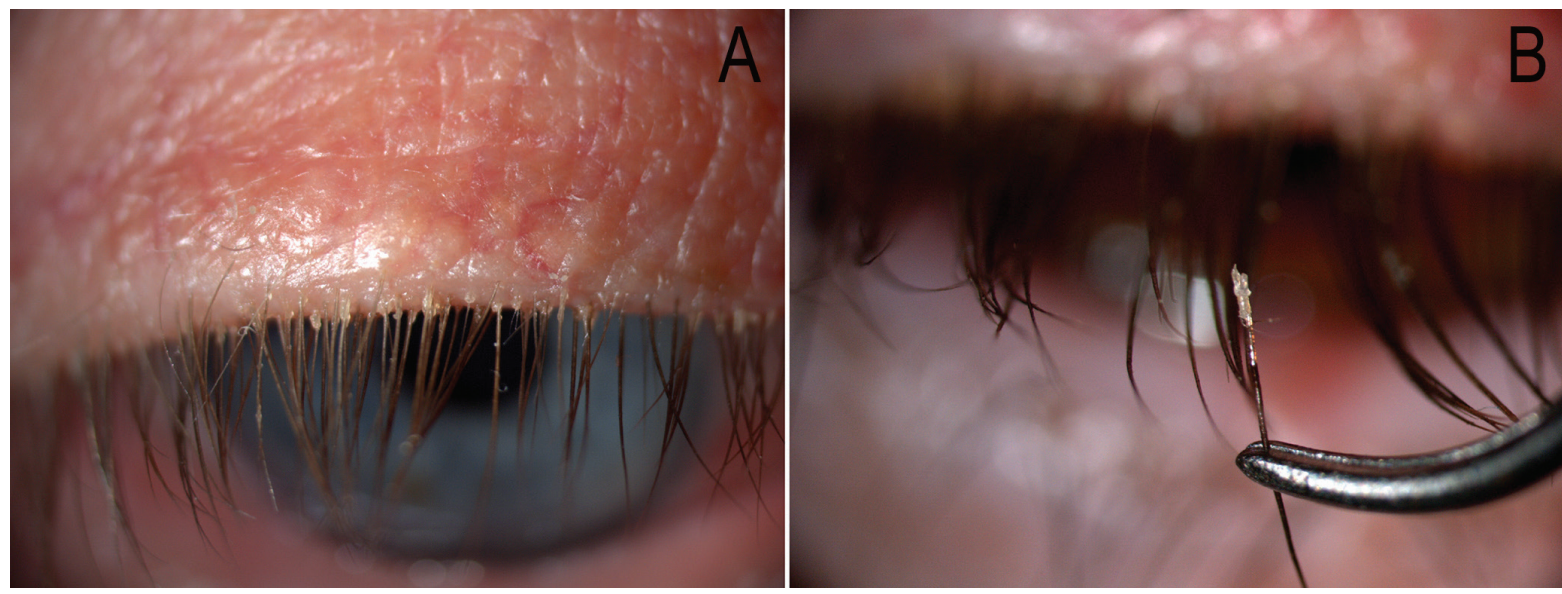

4. ábra

| Demodex-atka-fertőzést jelez a szempillák tövében megjelenő, azokat gyürúszerűen körülölelő 'collarette'

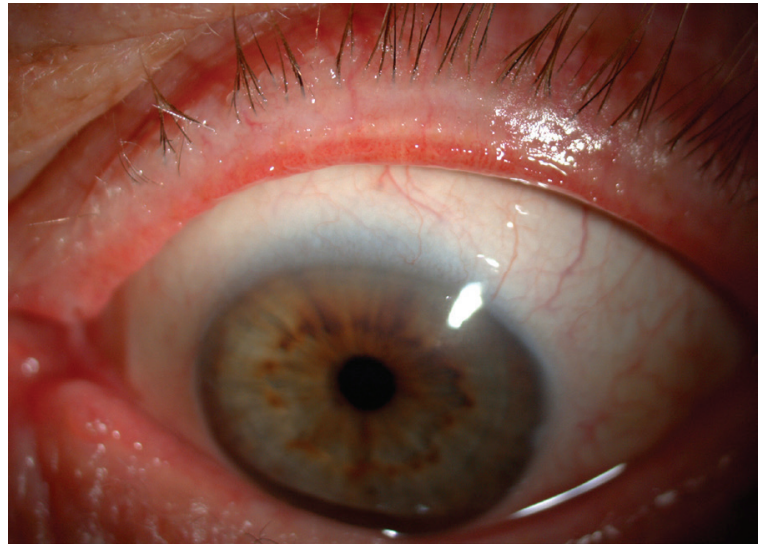

5. ábra

| Krónikus szemhéjszéli gyulladás képe

esetleges szemfelszíni károsodások vizsgálata. Szárazszem-tünetekkel rendelkező betegekben a diagnózishoz kérdőívek alkalmazása, valamint a pislantási gyakoriság, a könnymeniscus, a könnyozmolaritás, a szemfelszíni festődés, a könnyfilmfelszakadási idő és a könnytermelés mérése javasolt. A szemhéjszél morfológiájának vizsgálata, a meibum expresszálhatósága és minőségének megítélése is fontos (6. ábra). Az említett vizsgálatok alapján a Meibom-mirigy-diszfunkció a súlyossága alapján négy stádiumra osztható, amit úgynevezett „plusztünetek” egészíthetnek ki (6. ábra). A Meibom-mirigyek morfológiája és a múködő mirigyek eloszlása meibográfiával vizsgálható [18], melynek során az ép és a károsodott Meibom-mirigyek kimutathatók, a kiesés mértéke számszerüsíthető (7. ábra).

\section{Kezelés}

A Meibom-mirigy-diszfunkció kezelése alapvető a szárazszem-panaszok csökkentésében [19, 20]. Az MGD Workshop ajánlásai [14] alapján a betegség különböző stádiumaiban javasolt kezelési módokat a 8 ábra foglalja össze. A következőkben a terápiás lehetőségek közül a legfontosabbakat részletezzük.

\section{A szemhéjszél tisztitása}

Meibom-mirigy-diszfunkció esetén a rendellenes meibum magasabb olvadáspontú és sûrúbb állagú, a termelt meibum stagnálását és a kivezetőnyílások obstrukcióját okozva. A kivezetőnyílásokon lerakódott viaszsapka eltávolítására és így a meibumürülés elősegítésére korábban babasamponnal átitatott vattapálcás tisztítást ajánlottak, de ezt az utóbbi időben felváltotta a speciálisan erre a célra kifejlesztett, szemhéjszéli tisztítókendőkkel végzett kezelés. Klinikai tanulmányokban a betegek hatékonyabbnak és könnyebbnek ítélték meg a szemtörlő kendők használatát, mint a szappan, hígított sampon alkalmazását [21, 22]. Számos vizsgálat igazolta, hogy több héten át tartó, napi kétszeri alkalmazásuk eredményeképpen szignifikánsan javulnak a klinikai tünetek (a szemhéjszél állapota, gyulladásos jelek, a meibum minősége), illetve a szubjektív panaszok [23-27]. Továbbá már ötnapos kezelést követően is $60 \%$-kal csökken a kötőhártya baktériumflórája [28] és a posztoperatív endophthalmitis előfordulása. A különböző törlőkendők egységes tulajdonsága, hogy detergens hatású vegyületek mellett növényi eredetű hatóanyagokat és/vagy dezinficienseket tartalmaznak. A detergensek feladata a szemhéjszélen összegyúlt olajos-viaszos réteg eltávolítása, a Meibommirigy kivezetőcsöveinek szabaddá tétele (4. ábra). A terület tisztítása már önmagában jótékony hatású a fertőzések kezelésében, továbbá az antimikrobiális növényi hatóanyagok és dezinficiensek segítenek a bakteriális és a Demodex-fertőzések eliminálásában, a gyulladásos folyamatok enyhítésében. A tisztítás, fertőzés- és gyulladáscsökkentés eredményeképpen a Meibom-mirigyekből az olajos szekrétum könnyebben távozik, így a könnyfilm párolgása csökken, stabilitása nő.

\section{A Demodex-fertözés kezelése}

A szemhéjszéli Demodex-fertőzés csökkentésére a fizikai tisztításon kívül tartós, több hétig tartó antimikrobiális kezelésre is szükség van. A Demodex-fertőzés kezelésére 


Panaszok

6. ábra

Klinikai kép a Meibom-mirigy-diszfunkció különböző stádiumaiban (az MGD Workshop ajánlása alapján)

DEWS = Dry Eye Workshop; MGD = Meibom-mirigy-diszfunkció

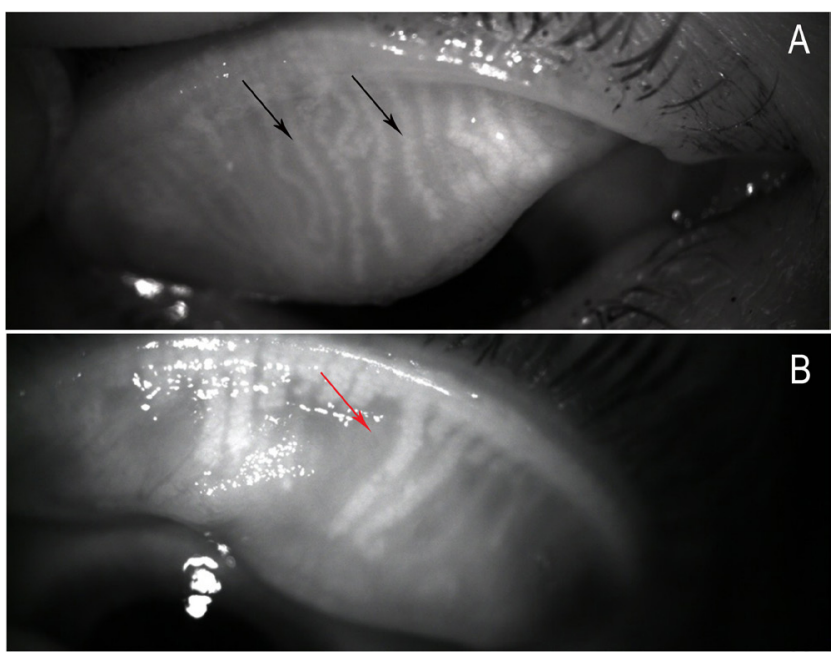

7. ábra

Infravörös fénnyel készült meibográfiás felvétel során jól láthatók az ép Meibom-mirigyek (nyilak) (A), melyek aránya kóros esetben jelentősen lecsökken (nyíl) (B)

4\%-os pilokarpingél, ivermektin $(0,1 \%)$ - metronidazolos (1\%) kenőcs, valamint az ezeknél hatékonyabb 1-10\%-os teafaolaj szolgálhat [29-31]. A teafaolaj a Melaleuca alternifolia növényböl nyerhető, antimikrobiális hatású illóolaj, mely ismerten vírus-, baktérium- és gombaellenes hatású. A teafaolaj hatékonyan gátolja a
Demodex-fertózést, csökkenti a szemfelszíni panaszokat in vitro és in vivo [32-35]. A teafaolaj antimikrobiális hatása függ annak koncentrációjától (9. ábra): míg alacsony koncentrációban nem kellően hatékony, addig túl magas koncentrációban irritálja a szemfelszínt, csípó érzést okoz. A szemkörnyék tisztítása teafaolaj-tartalmú szemhéjszéli tisztítókendővel hatékony otthoni kezelés a szemhéjak Demodex-fertőzésére, 1 hónapig tartó napi egyszeri alkalmazás eredményeképpen a betegek panaszai és a szemhéjszél Demodex-fertőzése szignifikánsan csökken [36]. A természetes teafaolaj 40-56\%-át kitevő terpinén-4-ol monokomponensként alkalmazva hatékonyabb és kevésbé irritál, mint az azonos koncentrációjú teafaolaj; ilyen összetételû szemhéjszéli tisztítókendő már Magyarországon is elérhető Ocuvane ${ }^{\circledR}$ Plus és Cliradex $^{\circledR}$ néven. A teafaolajat vagy terpinén-4-ol vegyületet tartalmazó szemhéjszéli tisztítókendők alkalmazása során a betegek a diszkomfortérzést nem jelentősnek és gyorsan múlónak jellemezték [37].

\section{A szembéjak melegitése}

A meibumürülés elősegítésére a fizikai tisztítás a szemhéjak melegítésével is kiegészíthető. A szemhéjak melegítésének hatására a Meibom-mirigyek kivezetőcsöveiben 


Kezelés

8. ábra

Az MGD Workshop ajánlása a Meibom-mirigy-diszfunkció kezelésére MGD $=$ Meibom-mirigy-diszfunkció

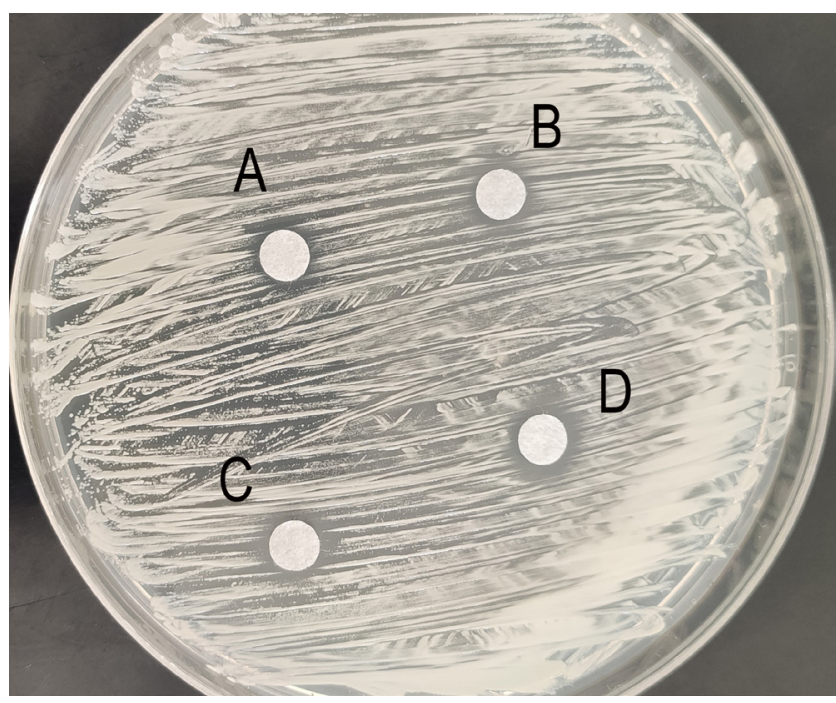

9. ábra

Emelkedő koncentrációjú $(\mathrm{A}<\mathrm{D})$ teafaolaj gátló hatása Staphylococcus aureus növekedésére 48 órás inkubációt követően

felgyülemlett olajos szekrétum elfolyósodik, könnyebben kiürül, aminek eredményeképpen a könnyfilm lipidrétegének vastagsága javul. A szemhéjak egy hónapon át tartó napi kétszeri melegítése Meibom-mirigy-diszfunkcióban szenvedő betegekben szignifikánsan javította a könnyfilmfelszakadási időt és a morfológiailag ép Meibom-mirigyek arányát [38]. Melegítő szemmaszk már Magyarországon is elérhető Relaxem ${ }^{\circledR}$ néven, ugyanakkor megjegyzendő, hogy a kezelés eredményes- sége változó, önállóan alkalmazva ritkán elégséges a panaszok megszüntetésére. Egy újabb kezelési lehetőség a LipiFlow ${ }^{\circledR}$ készülék alkalmazása. A 12 perces, orvos által végzett eljárás során a felső és alsó szemhéjakra felhelyezett melegítóeszköz egyidejúleg fokozatosan pulzáló nyomást gyakorol a szemhéjakra, azok széle felé irányulva, így a meibum a kivezetőcsövekből expresszálódik, és hosszú távon javítja a könnyfilm stabilitását. Egyszeri kezelést követően 1 hónappal a meibumtermelés és a könnyfilmfelszakadási idő szignifikáns javulását, valamint a szubjektív panaszok szignifikáns csökkenését írták le [39].

\section{Intenzio fénystimulációs kezelés}

Az intenzív fénystimulációs kezelés (E-Eye) során erôs, széles spektrumú (500-1200 nm), nem koherens villanófénnyel kezelik a szemhéjak környékén az arcbőrt 3-5 percig, a kezelést többször megismételve. Az alkalmazott fény a hemoglobinban elnyelődve a teleangiectasiák elzáródását, továbbá a gyulladás csökkenését eredményezi. Nyolc alkalommal végzett kezelést követően 32 héttel a szemhéjszél gyulladásos jeleinek és a szárazszem-panaszoknak a csökkenését, továbbá a könnyfilmfelszakadási idő növekedését (átlagosan 4,5 mp) írták le [40]. Ugyanakkor az eddig publikált randomizált vizsgálatok eredményei nem egységesek, további vizsgálatok szükségesek a beavatkozás eredményességének megítéléséhez [41]. 


\section{Lipidkomponensü mükönnyek}

A könnypótlás önmagában is előnyös hatású, ugyanis a Meibom-mirigy-diszfunkció az esetek 50-75\%-ában csökkent könnytermeléssel is társul, és a könnypótlás elősegíti a lipidréteg szétterülését, továbbá csökkenti a könnyfilmben levő gyulladásos citokinek mennyiségét. A Meibom-mirigy-diszfunkció okozta száraz szem tüneteinek enyhítésére az egyik gyakori terápiás lehetőség a könny pótlása különböző, lipidet is tartalmazó, „olaj a vízben” emulziós múkönnykészítményekkel. Nem lipidtartalmú múkönnyekkel összehasonlítva, lipidemulziós készítmények alkalmazásával 4 hetes kezelést követően a cseppentési gyakoriság kismértékben csökkent, amit a szaruhártya-festődés szignifikáns csökkenése és a könnyfilmfelszakadási idő javulása kísért [42].

\section{Lipidtartalmú liposzómás spray-k}

A könnyfilm lipidrétegének javulása a zárt szemhéjakra fújt liposzómás spray alkalmazásával is lehetséges, melynek foszfolipidtartalma egyesül a szemhéjszélen levő meibummal. Hat hétig történő kezelést követően a könnyfilmfelszakadási idő és a szemhéjszéli gyulladás szignifikáns javulását írták le [43].

\section{Gyógyszeres kezelés}

A szemhéjszél tisztításán és melegítésén kívül a Meibommirigy-diszfunkció előrehaladottabb formáinak kezelésére gyógyszeres terápia is szóba jöhet, elsősorban antibiotikumok, szteroid, immunmodulátorok, valamint hormonterápia formájában.

\section{Antibiotikumok}

A szemhéjakon és a kötőhártyán számos baktérium megtalálható, beleértve bizonyos Staphylococcus, Streptococcus, Corynebacterium és Propioni baktériumfajokat. Míg egyes fajok viszonylag jóindulatúak, a Staphylococus aureus vagy a Staphylococcus epidermidis megváltoztathatja a könnyfilm összetételét, miután az általuk termelt koleszterin- vagy viaszészterázok lebontják a könnyben levő lipideket. A tetraciklin jótékony hatásainak többsége a mikrobiális lipázok gátlásának, nem pedig közvetlen antimikrobiális hatásuknak tulajdonítható. A helyileg alkalmazott oxitetraciklin gátolja a bakteriális lipázokat, és megakadályozza a meibum lebomlását; ilyen készítmény Magyarországon Tetran szemkenőcs néven elérhető. A lokális kezelésre nem reagáló esetekben per os doxiciklin alkalmazása is szóba jöhet, mely lipofil tulajdonsága révén már 50-100 mg adag mellett bakteriosztatikus koncentrációt ér el a Meibom-mirigyekben. Egy hónapig tartó, napi $2 \times 200 \mathrm{mg}$ alkalmazását követően a szemhéjszéli gyulladásos jelek és a könnyfilmstabilitás szignifikáns javulását írták le, ugyanakkor a tartós antibiotikum- kezelés mellett kialakuló szisztémás mellékhatások miatt (gastrointestinalis panaszok, urticaria, pruritus) a kezelési mód alkalmazhatósága korlátozott [44].

\section{$N$-acetil-cisztein}

Meibom-mirigy-diszfunkció esetén 5\%-os N-acetil-cisztein-tartalmú szemcsepp 1 hónapos alkalmazását követően a könnyfilmfelszakadási idő és a könnytermelés szignifikáns javulását, továbbá az idegentest- és égő érzés szignifikáns csökkenését írták le [45]. A kezelés előnyös hatásai feltehetően a vegyület antikollagenolitikus, antioxidáns és gyulladáscsökkentő tulajdonságainak köszönhetők.

\section{Ómega-3 zsirsavak}

Több, randomizált vizsgálat metaanalízise alapján a táplálékkal bevitt ómega-3 esszenciális zsírsavak javítják a könnyfilmfelszakadási időt, a könnytermelést, és csökkentik a Meibom-mirigy-diszfunkció tüneteit [46]. Az ómega-3 zsírsavak hatásmechanizmusa nem tisztázott: feltehetôen javítják a meibum összetételét, illetve növelik az antiinflammatorikus ómega-3 zsírsavak és csökkentik a proinflammatorikus ómega-6 zsírsavak arányát [47].

\section{Szteroidok}

A helyileg alkalmazott szteroidok rövid távú alkalmazása előnyös lehet a gyulladással társuló formák kezelésében. Két hónapig tartó, a szemhéjak napi kétszeri melegítésével kiegészített 0,5\%-os loteprednol szemcsepp kezelés kapcsán a könnyfilmfelszakadási idő javulását, csökkenő kötőhártya- és szemhéjvörösséget, a könnyben mért gyulladásos citokinek csökkenését és a szubjektív panaszok javulását írták le [48]. Ugyanakkor, figyelembe véve a szteroidok lehetséges mellékhatásait (másodlagos zöld hályog és szürke hályog kialakulása), ez a kezelési mód csak a súlyosabb gyulladással járó folyamatok esetén, átmenetileg javasolt.

\section{Ciklosporin- $A$}

A 0,05\%-os ciklosporin-A tartalmú emulzió (Ikervis ${ }^{\circledR}$ ) gyulladás- és T-sejt-proliferáció-gátló hatása révén hatékonyan csökkenti a Meibom-mirigy-diszfunkció tüneteit. Három hónapig tartó alkalmazását követően a szemhéjszéli teleangiectasiák csökkenését, az OSDI-pontszám és a könnyfilmfelszakadási idő növekedését, a Meibommirigyek morfológiájának javulását írták le [49].

\section{Hormontartalmú gyógyszerek}

Hormontartalmú gyógyszerekkel feltételezhetően befolyásolható a könnyfilm lipidjeinek termelése, ugyanis a Meibom-mirigyek androgén receptorokat expresszálnak 
[50]. Ugyanakkor az eddigi eredmények nem konzisztensek, ugyanis a könnytermelés kismértékú javulása mellett a szubjektív panaszok romlását találták transdermalis tesztoszteron- és ösztrogénterápiában részesülő, menopausa után lévő nókben. További vizsgálatokra van szükség a hormonterápia hatékonyságának értékelésére a Meibom-mirigy-diszfunkció kezelésében.

\section{Következtetések}

A Meibom-mirigy-diszfunkció és az annak következtében kialakult könnytermelési zavarok és szárazszempanaszok előfordulása a várható életkor növekedésével, valamint a megváltozott életmóddal (kontaktlencse viselése, képernyő előtti munkavégzés) kapcsolatosan növekszik. A jellegzetes panaszok a leggyakrabban enyhék, és hatékonyan csökkenthetők a szemhéjszéli higiénia fenntartásával. A szemhéjak tisztítása megfelelő összetételü detergens és dezinficiens oldatokkal csökkenti a száraz szem okozta szemfelszíni panaszokat. A Meibom-mirigy-diszfunkcióhoz gyakran társuló Demodex-atka-fertőzés teafaolaj-tartalmú vagy annak monokomponensével impregnált szemhéjszéli tisztítókendőkkel kezelhető. A klinikai tapasztalatok alapján a kezelés eredményeképpen a Meibom-mirigyek kivezetőcsatornái átjárhatók lesznek, továbbá a bakteriális és Demodex-fertőzés a megfelelő lipidkiürülés és a fertőtlenítő kezelés együttes hatásaként megszünik. A könnyfilm olajos rétegének rendeződésével a könnyfilm zavarai, valamint az ezekből adódó szemfelszíni gyulladásos tünetek enyhülnek, a betegek panaszai csökkennek. A súlyosabb, kifejezett gyulladással társuló formákban átmenetileg antibiotikum- és gyulladásgátló kezelésre is szükség lehet, de hosszú távon a relapsus megelőzése a szemhéjszéli higiénia fenntartásán alapul.

Anyagi támogatás: A közlemény megírása, illetve a kapcsolódó kutatómunka nem részesült támogatásban.

Szerzői munkamegosztás: A vizsgálat tervezése: K. I., K. B. A vizsgálatok elvégzése: L. B., T.-N. A., H. Gy., Cs. A., K. H., Sz. I. A közlemény megírása: K. B., K. I., C. C., Sz. I. A közlemény kritikai revíziója: T.-N. A., H. Gy., N. Z. Zs. A cikk végleges változatát valamennyi szerző elolvasta és jóváhagyta.

Érdekeltségek: K. I. a SolMed Pharma Kft. alkalmazásában áll.

\section{Köszönetnyilvánítás}

Ezúton köszönjük $d r$. Kocsis Béla és $d r$. Lendvai Botond (Pécsi Tudományegyetem, Orvosi Mikrobiológiai és Immunitástani Intézet; Gyógyszertechnológiai és Biofarmáciai Intézet) szíves közremúködését.

\section{Irodalom}

[1] Knop E, Knop N, Millar T, et al. The International Workshop on Meibomian Gland Dysfunction: report of the Subcommittee on Anatomy, Physiology, and Pathophysiology of the Meibomian Gland. Invest Ophthalmol Vis Sci. 2011; 52: 1938-1978.

[2] Berta A, Tóth-Molnár E, Csutak A. New international consensus statement about the definition, classification, ethiology, diagnostics and therapy of dry eye (TFOS DEWS II). [Új nemzetközi konszenzusnyilatkozat a száraz szem definíciójáról, felosztásáról, etiológiájáról, diagnosztikájáról és terápiájáról.] Orv Hetil. 2018; 159: 775-785. [Hungarian]

[3] Schaumberg DA, Nichols JJ, Papas EB, et al. The International Workshop on Meibomian Gland Dysfunction: report of the subcommittee on the epidemiology of, and associated risk factors for, MGD. Invest Ophthalmol Vis Sci. 2011; 52: 1994-2005

[4] Borchman D, Foulks GN, Yappert MC, et al. Human meibum lipid conformation and thermodynamic changes with meibomian-gland dysfunction. Invest Ophthalmol Vis Sci. 2011; 52: 3805-3817.

[5] Shimazaki J, Sakata M, Tsubota K. Ocular surface changes and discomfort in patients with meibomian gland dysfunction. Arch Ophthalmol. 1995; 113: 1266-1270.

[6] Dougherty JM, McCulley JP. Comparative bacteriology of chronic blepharitis. Br J Ophthalmol. 1984; 68: 524-528.

[7] Liu J, Sheha H, Tseng SC. Pathogenic role of Demodex mites in blepharitis. Curr Opin Allergy Clin Immunol. 2010; 10: 505510.

[8] Lee SH, Chun YS, Kim JH, et al. The relationship between Demodex and ocular discomfort. Invest Ophthalmol Vis Sci. 2010; 51: 2906-2911.

[9] Kim JH, Chun YS, Kim JC. Clinical and immunological responses in ocular demodecosis. J Korean Med Sci. 2011; 26: 12311237.

[10] Management and therapy of dry eye disease: report of the Management and Therapy Subcommittee of the International Dry Eye WorkShop (2007). Ocul Surf. 2007; 5: 163-178.

[11] Post CF, Juhlin E. Demodex folliculorum and blepharitis. Arch Dermatol. 1963; 88: 298-302.

[12] Jalbert I, Rejab S. Increased numbers of Demodex in contact lens wearers. Optom Vis Sci. 2015; 92: 671-678.

[13] Preisz K, Kárpáti S. Rosacea: pathogenesis, clinical forms and therapy. [A rosacea patogenezise, klinikai formái és kezelése.] Orv Hetil. 2010; 151: 1209-1214. [Hungarian]

[14] Geerling G, Tauber J, Baudouin C, et al. The International Workshop on Meibomian Gland Dysfunction: report of the Subcommittee on Management and Treatment of Meibomian Gland Dysfunction. Invest Ophthalmol Vis Sci. 2011; 52: 2050-2064.

[15] Dougherty JM, McCulley JP. Bacterial lipases and chronic blepharitis. Invest Ophthalmol Vis Sci. 1986; 27: 486-491.

[16] Mastrota KM. Method to identify Demodex in the eyelash follicle without epilation. Optom Vis Sci. 2013; 90: el72-e174.

[17] Coston TO. Demodex folliculorum blepharitis. Trans Am Ophthalmol Soc. 1967; 65: 361-392.

[18] Methodologies to diagnose and monitor dry eye disease: report of the Diagnostic Methodology Subcommittee of the International Dry Eye WorkShop. Ocul Surf. 2007; 5: 108-152.

[19] Tóth-Molnár E. Treatment of dry eye disease. Present and future. [A száraz szem kezelésének stratégiája: jelenlegi ajánlások, jövőbeni lehetőségek.] Szemészet 2020; 157: 1-10. [Hungarian]

[20] Módis L. Therapy of the dry eye disease. In: Süveges I. (ed.) Ocular surface and cornea diseases. [A száraz szem terápiája. In: Süveges I. (szerk.) A szemfelszín és cornea betegségei.] Medicina Könyvkiadó, Budapest, 2020; pp. 45-63. [Hungarian] 
[21] Key JE. A comparative study of eyelid cleaning regimens in chronic blepharitis. CLAO J. 1996; 22: 209-212.

[22] Guillon M, Maissa C, Wong S. Eyelid margin modification associated with eyelid hygiene in anterior blepharitis and meibomian gland dysfunction. Eye Contact Lens 2012; 38: 319-325.

[23] Korb DR, Blackie CA, Finnemore VM, et al. Effect of using a combination of lid wipes, eye drops, and omega- 3 supplements on meibomian gland functionality in patients with lipid deficient/evaporative dry eye. Cornea 2015; 34: 407-412.

[24] Jackson WB. Blepharitis: current strategies for diagnosis and management. Can J Ophthalmol. 2008; 43: 170-179.

[25] Wong K, Flanagan J, Jalbert I, et al. The effect of Blephadex ${ }^{\mathrm{TM}}$ eyelid wipes on Demodex mites, ocular microbiota, bacterial lipase and comfort: a pilot study. Cont Lens Anterior Eye 2019; 42: 652-657.

[26] Greiner JV, Leahy CD, Glonek T, et al. Effects of eyelid scrubbing on the lid margin. CLAO J. 1999; 25: 109-113.

[27] Hueso Abancens JR, Mengual Verdú E, Schargel Palacios K, et al. Modification of the conjuntival flora with cleaning palpebral solutions. [Modificación de la flora conjuntival por el empleo de soluciones de higiene palpebral.] Arch Soc Esp Oftalmol. 2004; 79: 617-621. [Spanish]

[28] Peral A, Alonso J, García-García C, et al. Importance of lid hygiene before ocular surgery: qualitative and quantitative analysis of eyelid and conjunctiva microbiota. Eye Contact Lens 2016; 42: 366-370

[29] Ávila MY, Martínez-Pulgarín DF, Rizo Madrid C. Topical ivermectin-metronidazole gel therapy in the treatment of blepharitis caused by Demodex spp.: a randomized clinical trial. Cont Lens Anterior Eye 2020 May 24. Doi: 10.1016/j.clae.2020.04.011. [Online ahead of print]

[30] Fulk GW, Murphy B, Robins MD. Pilocarpine gel for the treatment of demodicosis - a case series. Optom Vis Sci. 1996; 73 : 742-745.

[31] Jones L, Downie LE, Korb D, et al. TFOS DEWS II management and therapy report. Ocul Surf. 2017; 15: 575-628.

[32] Hammer K, Carson, Riley CT. Antifungal activity of the components of Melalenca alternifolia (tea tree) oil. J Appl Microbiol. 2003; 95: 853-860.

[33] Gao YY, DiPascuale MA, Li W, et al. In vitro and in vivo killing of ocular Demodex by tea tree oil. Br J Ophthalmol. 2005; 89: $1468-1473$

[34] Gao YY, Xu D, Huang IJ, et al. Treatment of ocular itching associated with ocular demodicosis by $5 \%$ tea tree oil ointment. Cornea 2012; 31: 14-17.

[35] Kabat AG. In vitro demodicidal activity of commercial lid hygiene products. Clin Ophthalmol. 2019; 13: 1493-1497.

[36] Gao YY, Di Pascuale MA, Elizondo A, et al. Clinical treatment of ocular demodecosis by lid scrub with tea tree oil. Cornea 2007; 26: 136-143.

[37] Ngo W, Jones L, Bitton E. Short-term comfort responses associated with the use of eyelid cleansing products to manage Demo- dex folliculorum. Eye Contact Lens 2018; 44(Suppl 2): S87S92.

[38] Arita R, Morishige N, Shirakawa R, et al. Effects of eyelid warming devices on tear film parameters in normal subjects and patients with meibomian gland dysfunction. Ocul Surf. 2015; 13: 321-330.

[39] Greiner JV. Long-term (12-month) improvement in meibomian gland function and reduced dry eye symptoms with a single thermal pulsation treatment. Clin Exp Ophthalmol. 2013; 41: 524530.

[40] Arita R, Fukuoka S, Morishige N. Therapeutic efficacy of intense pulsed light in patients with refractory meibomian gland dysfunction. Ocul Surf. 2019; 17: 104-110.

[41] Cote S, Zhang AC, Ahmadzai V, et al. Intense pulsed light (IPL) therapy for the treatment of meibomian gland dysfunction. Cochrane Database Syst Rev. 2020; 3: CD013559.

[42] Sindt CW, Foulks GN. Efficacy of an artificial tear emulsion in patients with dry eye associated with meibomian gland dysfunction. Clin Ophthalmol. 2013; 7: 1713-1722.

[43] Dausch D, Lee S, Dausch S, et al. Comparative study of treatment of the dry eye syndrome due to disturbances of the tear film lipid layer with lipid-containing tear substitutes. [Vergleichende Studie zur Therapie des trockenen Auges bedingt durch Lipidphasenstörungen mit lipidhaltigen Tränenpräparaten.] Klin Monbl Augenheilkd. 2006; 223: 974-983. [German]

[44] Wladis EJ, Bradley EA, Bilyk JR, et al. Oral antibiotics for meibomian gland-related ocular surface disease: a report by the American Academy of Ophthalmology. Ophthalmology 2016; 123: 492-496.

[45] Akyol-Salman I, Azizi S, Mumcu U, et al. Efficacy of topical Nacetylcysteine in the treatment of meibomian gland dysfunction. J Ocul Pharmacol Ther. 2010; 26: 329-333.

[46] Liu A, Ji J. Omega-3 essential fatty acids therapy for dry eye syndrome: a meta-analysis of randomized controlled studies. Med Sci Monit. 2014; 20: 1583-1589.

[47] Calder PC. Polyunsaturated fatty acids, inflammation, and immunity. Lipids 2001 ; 36: 1007-1024.

[48] Lee H, Chung B, Kim KS, et al. Effects of topical loteprednol etabonate on tear cytokines and clinical outcomes in moderate and severe meibomian gland dysfunction: randomized clinical trial. Am J Ophthalmol. 2014; 158: 1172-1183.el.

[49] Perry HD, Doshi-Carnevale S, Donnenfeld ED, et al. Efficacy of commercially available topical cyclosporine A $0.05 \%$ in the treatment of meibomian gland dysfunction. Cornea 2006; 25: 171175.

[50] Sullivan DA, Sullivan BD, Ullman MD, et al. Androgen influence on the meibomian gland. Invest Ophthalmol Vis Sci. 2000; 41: 3732-3742.

(Kovács Illés dr., Budapest, Üllői út 26., 1085 e-mail: kovacs.illes@med.semmelweis-univ.hu)

A cikk a Creative Commons Attribution 4.0 International License (https://creativecommons.org/licenses/by/4.0/) feltételei szerint publikált Open Access közlemény, melynek szellemében a cikk bármilyen médiumban szabadon felhasználható, megosztható és újraközölhetö, feltéve, hogy az eredeti szerző és a közlés helye, illetve a CC License linkje és az esetlegesen végrehajtott módosítások feltüntetésre kerülnek. (SID_1) 